\title{
Vitamin D deficiency and adverse fetal outcome
}

\author{
Anu B. Chandel ${ }^{1 *}$, Anoop Sharma ${ }^{1}$, Rita Mittal ${ }^{1}$, Shivika Mittal ${ }^{2}$
}

\begin{abstract}
${ }^{1}$ Department of Obstetrics and Gynecology, Kamla Nehru Hospital, Shimla, Himachal Pradesh, India
${ }^{2}$ Department of Obstetrics and Gynecology, RPGMC, Tanda, Kangra, Himachal Pradesh, India
\end{abstract}

Received: 02 May 2020

Accepted: 30 May 2020

\section{*Correspondence:}

Dr. Anu B. Chandel,

E-mail: anuchande107@gmail.com

Copyright: () the author(s), publisher and licensee Medip Academy. This is an open-access article distributed under the terms of the Creative Commons Attribution Non-Commercial License, which permits unrestricted non-commercial use, distribution, and reproduction in any medium, provided the original work is properly cited.

\begin{abstract}
Background: Vitamin D deficiency is recognized as the most untreated nutritional deficiency in the world. It is plausible that vitamin D deficiency could make the fetal heart more vulnerable to distress/birth asphyxia. Vitamin D deficiency has been hypothesized to be associated with low birth weight, low Apgar score at birth, higher rates of still births and admission to NICU. The aim of present study was to study prevalence of vitamin D deficiency in pregnancy and evaluate perinatal outcome.

Methods: The study was conducted in the department of obstetrics and gynecology, Kamla Nehru Hospital, Shimla, India over a period of 12 months. Six hundred women were included in the study.

Results: All the mothers who had still births suffered from vitamin D deficiency and the severe vitamin D deficiency was there in $90.91 \%$ (30) of these subjects. Severe vitamin D deficiency was seen in $78.95 \%$ (75) of the subjects having babies with birth weights $<2.5 \mathrm{~kg}$ compared to $61.16 \%$ (288) subjects of the other group.

Conclusions: Adverse fetal outcome are more common in vitamin D deficient group.
\end{abstract}

Keywords: Apgar score, Neonatal intensive care unit, Still birth, Vitamin D deficiency

\section{INTRODUCTION}

Vitamin D deficiency is recognized as the most untreated nutritional deficiency in the world.

At no other time during the life cycle, is vitamin D status more important than during pregnancy, as mother is the sole source of vitamin D substrate for her developing fetus. $^{2}$

Vitamin D is important for postnatal muscle strength. Birth asphyxia is associated with cardiovascular dysfunction, including low ventricular output, lower left ventricular ejection fraction and increased troponin levels. Congestive heart failure may occur in severe cases of asphyxia. It is plausible that vitamin D deficiency could make the fetal heart more vulnerable to distress/birth asphyxia. Several studies have reported increased frequency of emergency caesarean delivery in relation to low vitamin D levels. ${ }^{3}$

Neonatal vitamin D levels are correlated with those of their mother, with maternal vitamin D deficiency increasing the risk of neonatal vitamin D deficiency. In an Australian study, hypovitaminosis D was found in $15 \%$ of pregnant women and $11 \%$ of neonates. Vitamin D deficiency is a major cause of hypocalcaemic seizures in neonates and infants. Hypocalcaemia is not uncommon in neonates and is a potentially severe problem. Mothers of babies who suffer hypocalcaemic seizures are more likely to be vitamin $\mathrm{D}$ deficient $(85 \%)$ than mothers of babies who do not $(50 \%)$. In another study from Egypt, all mothers of babies with hypocalcaemic seizures had severe vitamin D deficiency. Maternal vitamin D deficiency is a common, and potentially preventable, cause of neonatal hypocalcaemia. This is especially common in South Asian women. ${ }^{4}$ 
Vitamin D deficiency has been associated with low birth weight and admission to NICU.

\section{METHODS}

Observational study conducted in the department of obstetrics and gynecology, Kamla Nehru State Hospital for Mother and child, IGMC, Shimla, India w.e.f. $1^{\text {st }}$ August 2017 to $31^{\text {st }}$ July 2018. All women fulfilling the inclusion criteria were included in the study.

\section{Inclusion criteria}

- $\quad$ Age 18-40 years

- Primigravida

- Confirmed viable singleton intrauterine pregnancy

- $\quad$ POG more than or equal to 28 weeks.

\section{Exclusion criteria}

- Current or past medical illness which may interfere with vitamin $\mathrm{D}$ and calcium levels such as hyperparathyroidism, collagen diseases, Cushing's disease, chronic renal disease, GI disease, lung cancer and ovarian tumours

- Taking medications that interfere with vitamin D and calcium

- Levels-anticonvulsants, corticosteroids, thiazides, thyroxine, heparin, antitubercular drugs

- Known case of diabetes, hypertension

- Multiple pregnancy

- Multiparity.

Six hundred women fulfilling the inclusion criteria at POG >=28 weeks of pregnancy and delivering in labour room of our hospital were included after written informed consent. Information on age, education, occupation, income, religion, diet, vitamin supplements and dairy products intake, exposure to sunlight etc. was obtained from the subjects using a questionnaire. A fasting blood sample of minimum $2 \mathrm{ml}$ was taken and was tested for serum 25(OH)D by CMIA (chemiluminescent microparticle immunoassay) method in hospital lab. LCMS/MS (liquid chromatography-mass spectrometry) procedure was used for vitamin D quantification.

The patients were categorised as per the levels:

- Severe deficiency - <10 ng/ml

- Moderate deficiency - 10-19.9 ng/ml

- Mild deficiency - 20-29.9 ng/ml

- Optimal level >=30 ng/ml.

\section{Statistical analysis}

All the data was entered in Microsoft excel 2007 spreadsheet. Categorical variables were analysed using Chi square and Fischer exact test. Continuous variables were analysed using the appropriate tests after checking for the normality distribution using Kolmogrov Smirnoff test.

- $\quad(\mathrm{S})=$ significant

- $\quad(\mathrm{NS})=$ not significant.

A p-value of 0.05 or less was considered statistically significant.

\section{RESULTS}

Out of 600 subjects, $32(5.33 \%)$ subjects had sufficient vitamin D levels and $568(94.67 \%)$ had vitamin D deficiency. Among the vitamin D deficient subjects, 46 (7.66\%) had mild, 159 (26.50\%) had moderate and 363 $(60.50 \%)$ had severe vitamin D deficiency.

Table 1: Vitamin D levels and still births.

\begin{tabular}{|c|c|c|c|c|c|c|c|c|c|c|c|}
\hline $\begin{array}{l}\text { Births } \\
(n=600)\end{array}$ & \multicolumn{2}{|c|}{$\begin{array}{l}\text { Vitamin D } \\
\text { sufficiency } \\
(n=32)\end{array}$} & \multicolumn{2}{|c|}{$\begin{array}{l}\text { Vitamin D } \\
\text { deficiency } \\
(\mathrm{n}=568)\end{array}$} & \multicolumn{2}{|c|}{$\begin{array}{l}\text { Mild } \\
\text { deficiency } \\
(\mathrm{n}=46)\end{array}$} & \multicolumn{2}{|c|}{$\begin{array}{l}\text { Moderate } \\
\text { deficiency } \\
(\mathrm{n}=159)\end{array}$} & \multicolumn{2}{|c|}{$\begin{array}{l}\text { Severe } \\
\text { deficiency } \\
(n=363)\end{array}$} & $\begin{array}{l}p \\
\text { value }\end{array}$ \\
\hline $\begin{array}{l}\text { Live birth } \\
(\mathrm{n}=567,94.5 \%)\end{array}$ & 32 & $5.45 \%$ & 535 & $94.35 \%$ & 45 & $8.42 \%$ & 157 & $29.35 \%$ & 333 & $62.2 \%$ & \multirow{2}{*}{$\begin{array}{l}0.31 \\
(\mathrm{NS})\end{array}$} \\
\hline $\begin{array}{l}\text { Still birth }(\mathrm{n}=33 \text {, } \\
5.5 \%)\end{array}$ & 0 & $0 \%$ & 33 & $100 \%$ & 1 & $3.03 \%$ & 2 & $6.06 \%$ & 30 & $90.9 \%$ & \\
\hline
\end{tabular}

Table 1 depicts the distribution of the subjects according to live births/still births of the babies. 567 (94.5\%) babies were live born and $33(5.5 \%)$ were still born.

Among the vitamin D sufficient group, all 32 subjects had live birth and none had still birth, however in vitamin
D deficient group, 535 (94.19\%) subjects had live born babies while $33(5.81 \%)$ subjects had still born babies.

It can be clearly interpreted that all the mothers who had still births suffered from vitamin $D$ deficiency and the severe vitamin D deficiency was there in $90.91 \%$ (30) of these subjects. 
As depicted in Table 2, out of 600, 97 (16.17\%) babies were having weight $<2.5 \mathrm{~kg}$ and $503(83.83 \%)$ were having weight $>2.5 \mathrm{~kg}$.
Among the vitamin sufficient group, 2 (6.25\%) subjects had babies weighing less than $2.5 \mathrm{~kg}$ while 30 (93.75\%) subjects had babies with birth weight more than $2.5 \mathrm{~kg}$.

Table 2: Vitamin D levels and birth weight of baby.

\begin{tabular}{|c|c|c|c|c|c|c|c|c|c|c|c|}
\hline $\begin{array}{l}\text { Total } \\
(n=600)\end{array}$ & \multicolumn{2}{|c|}{$\begin{array}{l}\text { Vitamin D } \\
\text { sufficiency } \\
(\mathrm{n}=32)\end{array}$} & \multicolumn{2}{|c|}{$\begin{array}{l}\text { Vitamin D } \\
\text { deficiency } \\
(\mathrm{n}=\mathbf{5 6 8})\end{array}$} & \multicolumn{2}{|c|}{$\begin{array}{l}\text { Mild } \\
\text { deficiency } \\
(\mathrm{n}=46)\end{array}$} & \multicolumn{2}{|c|}{$\begin{array}{l}\text { Moderate } \\
\text { deficiency } \\
(\mathbf{n}=159)\end{array}$} & \multicolumn{2}{|c|}{$\begin{array}{l}\text { Severe } \\
\text { deficiency } \\
(n=363)\end{array}$} & $\begin{array}{l}\mathbf{p} \\
\text { value }\end{array}$ \\
\hline $\begin{array}{l}\text { Birth weight }<=2.5 \mathrm{~kg} \\
(\mathrm{n}=97,16.17 \%)\end{array}$ & 2 & $2.06 \%$ & 95 & $97.94 \%$ & 5 & $5.26 \%$ & 15 & $15.79 \%$ & 75 & $78.95 \%$ & \multirow{2}{*}{$\begin{array}{l}0.22 \\
(\mathrm{NS})\end{array}$} \\
\hline $\begin{array}{l}\text { Birth weight }>2.5 \mathrm{~kg} \\
(\mathrm{n}=503,83.83 \%)\end{array}$ & 30 & $5.96 \%$ & 473 & $94.04 \%$ & 41 & $8.67 \%$ & 144 & $30.44 \%$ & 288 & $60.89 \%$ & \\
\hline
\end{tabular}

Table 3: Vitamin D levels and Apgar Score at birth.

\begin{tabular}{|c|c|c|c|c|c|c|c|c|c|c|c|}
\hline $\begin{array}{l}\text { Total } \\
(n=600)\end{array}$ & \multicolumn{2}{|c|}{$\begin{array}{l}\text { Vitamin D } \\
\text { sufficiency } \\
(n=32)\end{array}$} & \multicolumn{2}{|c|}{$\begin{array}{l}\text { Vitamin D } \\
\text { deficiency } \\
(\mathrm{n}=568)\end{array}$} & \multicolumn{2}{|c|}{$\begin{array}{l}\text { Mild deficiency } \\
(n=46)\end{array}$} & \multicolumn{2}{|c|}{$\begin{array}{l}\text { Moderate } \\
\text { deficiency } \\
(\mathrm{n}=159)\end{array}$} & \multicolumn{2}{|c|}{$\begin{array}{l}\text { Severe } \\
\text { deficiency } \\
(\mathrm{n}=363)\end{array}$} & $\begin{array}{l}\mathbf{p} \\
\text { value }\end{array}$ \\
\hline $\begin{array}{l}\text { Apgar<7 }(n=118, \\
19.67 \%)\end{array}$ & 3 & $2.54 \%$ & 115 & $97.46 \%$ & 8 & $6.96 \%$ & 24 & $20.87 \%$ & 83 & $72.17 \%$ & \multirow{2}{*}{$\begin{array}{l}0.20 \\
(\mathrm{NS})\end{array}$} \\
\hline $\begin{array}{l}\text { Apgar }>=7 \\
(\mathrm{n}=482,80.33 \%)\end{array}$ & 29 & $6.02 \%$ & 453 & $93.98 \%$ & 38 & $8.39 \%$ & 135 & $29.80 \%$ & 280 & $61.81 \%$ & \\
\hline
\end{tabular}

Table 4: Admissions to NICU.

\begin{tabular}{|c|c|c|c|c|c|c|c|c|c|c|}
\hline $\begin{array}{l}\text { Admission to NICU } \\
(n=600)\end{array}$ & $\begin{array}{l}\text { Vitamin D } \\
\text { sufficiency } \\
(n=32)\end{array}$ & $\begin{array}{l}\text { Vita } \\
\text { defii } \\
(n=5\end{array}$ & & & iciency & $\begin{array}{l}\text { Moc } \\
\text { defi } \\
(n=1\end{array}$ & $\begin{array}{l}\text { irate } \\
\text { ency } \\
\text { 59) }\end{array}$ & $\begin{array}{l}\text { Sev } \\
\text { def } \\
(n=\end{array}$ & $\begin{array}{l}\text { e } \\
\text { ency } \\
3 \text { 3) }\end{array}$ & $\begin{array}{l}\mathbf{p} \\
\text { value }\end{array}$ \\
\hline Yes $(n=105,17.5 \%)$ & $1.90 \%$ & 103 & $98.10 \%$ & 8 & $7.77 \%$ & 22 & $21.36 \%$ & 73 & $70.87 \%$ & \multirow{2}{*}{$\begin{array}{l}0.13 \\
\text { (NS) }\end{array}$} \\
\hline No $(n=495,82.5 \%)$ & $30 \quad 6.06 \%$ & 465 & $93.94 \%$ & 38 & $8.17 \%$ & 137 & $29.46 \%$ & 290 & $62.37 \%$ & \\
\hline
\end{tabular}

In the vitamin D deficient group, 95 (16.73\%) subjects had baby birth weights less than $2.5 \mathrm{~kg}$ whereas 473 $(83.27 \%$ ) subjects had babies weighing more than $2.5 \mathrm{~kg}$.

Severe vitamin D deficiency was seen in $78.95 \%$ (75) of the subjects having babies with birth weights $<2.5 \mathrm{~kg}$ compared to $61.16 \%$ (288) subjects of the other group, thus vitamin D deficiency has definite impact upon the growth of fetus.

Table 3 depicts the distribution of the subjects according to Apgar score of their babies. Out of 600 subjects, 118 (19.67\%) babies had Apgar <7 and 482 (80.32\%) had Apgar $>7$. Out of 118 subjects, only 3 (2.54\%) mothers had sufficient vitamin D levels and $115(97.46 \%)$ had vitamin D deficiency, further $83(72.17 \%)$ subjects had severe vitamin $\mathrm{D}$ deficiency.

Among the rest of 482 subjects, 29 (6.02\%) had sufficient vitamin D levels and $453(93.98 \%)$ had vitamin D deficiency, however the difference was not statistically significant ( $\mathrm{p}$ value $=0.20)$.

Table 4 depicts the distribution of the subjects according to admission to NICU of their babies. Out of 600 subjects, 105 (17.5\%) babies were admitted to NICU and $495(82.5 \%)$ were not admitted in the NICU.

Out of 105 subjects whose babies were admitted in NICU, only $2(1.90 \%)$ mothers had sufficient vitamin D levels while 103 (98.10\%) had vitamin D deficiency. Among the 103 vitamin D deficient mothers, 73 (70.87\%) had severe vitamin D deficiency but the association was not statistically significant $(\mathrm{p}$ value $=0.13$ ).

\section{DISCUSSION}

It is clearly evident from Table 1 that all still births occurred in women who were vitamin $\mathrm{D}$ deficient. The results were corresponding to the study conducted by Chauhan $\mathrm{N}$ et al. ${ }^{5}$ However in study conducted by Prasad $\mathrm{D}$ et al, still births occurred comparatively more in women with vitamin D deficiency $83.33 \%$ versus $16.67 \%$ in vitamin D sufficient group. ${ }^{1}$

In this study vitamin $\mathrm{D}$ deficiency was slightly more in mothers whose babies had birth weight less than $2.5 \mathrm{~kg}$ compared to subjects in whom birth weight were more than $2.5 \mathrm{~kg}$ i.e. $97.94 \%$ versus $94.04 \%$. Similar results were also observed in studies conducted by Nageshu $\mathrm{S}$ et 
al, Dave A et al, Prasad D et al, Chauhan $\mathrm{N}$ et al. ${ }^{1,6,7}$ Vitamin D deficiency predisposes to low birth weights in babies.

Table 4 depicts the distribution of subjects according to NICU admissions of their babies. As per this study, $98.10 \%$ of the subjects whose babies were admitted in the NICU, had vitamin D deficiency, which is similar to the studies conducted by Nageshu $\mathrm{S}$ et al and Prasad D et al i.e., $87.5 \%$ and $90 \%$ respectively. ${ }^{1,6}$

Vitamin D deficiency makes the fetal heart more vulnerable to fetal distress or birth asphyxia, thus increasing the NICU admissions in babies.

\section{CONCLUSION}

This study concludes that there is high prevalence of vitamin $\mathrm{D}$ deficiency in pregnancy. Adverse perinatal outcome was more prevalent in the vitamin D deficient group, however more studies are required to establish the direct correlation.

Authors recommend encouragement of outdoor activities, exposure to sunlight, and vitamin D supplementation in those with insufficient vitamin D levels.

\section{Funding: No funding sources}

Conflict of interest: None declared

Ethical approval: The study was approved by the Institutional Ethics Committee

\section{REFERENCES}

1. Prasad D, Smita, Singh K, Nisha S. Vitamin D in pregnancy and its correlation with feto maternal outcome. Int J Contemp Med Res. 2018;5(1):1-5.

2. Singh N, Kumar D, Singh J, Chandanan A. A study of vitamin D, its supplementation and effect on fetomaternal outcome during pregnancy. Indian $\mathbf{J}$ Res. 2015;4(9):270-2.

3. Lindqvist PG, Silva AT, Gustafsson SA. Gidl of Sebastian. Maternal vitamin D deficiency and fetal distress/birth asphyxia: a population based nested case-control study. BMJ Open. 2016;6:e009733.

4. Royal college of obstetricians and gynecologists. vitamin D in pregnancy. Scientific Impact Paper No 43. London: RCOG; 2014.

5. Chauhan N, Pahuja N, Kalra V. Correlation of Vitamin D levels with feto-maternal outcome. Int $\mathbf{J}$ Reprod Contracept Obstet Gynecol. 2017;7(1):13741.

6. Nageshu S, Krishna K, Krishna L, Bhat B, Suma H, Reddy S. A study of prevalence of Vitamin D deficiency among pregnant women and its impact on feto maternal outcome. Int $\mathbf{J}$ Reprod Contracept Obstet Gynecol. 2016;4(4):1174-80.

7. Dave A, Verma AM, Jain N, Dave A. A study of vitamin D levels and associated deficiency in pregnancy and its effect on maternal and fetal outcome. Int J Reprod Contracep Obstet Gynecol. 2017;6(1):84-8.

Cite this article as: Chandel $\mathrm{AB}$, Sharma A, Mittal R, Mittal S. Vitamin D deficiency and adverse fetal outcome. Int J Reprod Contracept Obstet Gynecol 2020;9:2891-4. 